\title{
Chronic Prenatal Hypoxia Down-Regulated BK Channel B1 Subunits in Mesenteric Artery Smooth Muscle Cells of the Offspring
}

\author{
Bailin Liua Yanping Liu ${ }^{a}$ Ruixiu Shi ${ }^{a}$ Xueqin Fenga Xiang Lia Wenna Zhang ${ }^{a}$ \\ Jue Wua $\mathrm{Na} \mathrm{Li}^{\mathrm{a}}$ Xiuwen Zhou ${ }^{\mathrm{a}}$ Miao Sun ${ }^{\mathrm{a}}$ Zhice Xu $\mathrm{Xu}^{\mathrm{a}, \mathrm{b}}$ \\ anstitute for Fetology, First Hospital of Soochow University, Suzhou, China, ${ }^{b}$ Center for Perinatal \\ Biology, Loma Linda University, California, USA
}

\section{Key Words}

Bk channel • $\beta 1$-subunit $•$ Mesenteric artery $\bullet$ Smooth muscle cells $•$ Prenatal hypoxia

\begin{abstract}
Background/Aims: Chronic hypoxia in utero could impair vascular functions in the offspring, underlying mechanisms are unclear. This study investigated functional alteration in largeconductance $\mathrm{Ca}^{2+}$-activated $\mathrm{K}^{+}(\mathrm{BK})$ channels in offspring mesenteric arteries following prenatal hypoxia. Methods: Pregnant rats were exposed to normoxic control $\left(21 \% \mathrm{O}_{2^{\prime}}\right.$ Con) or hypoxic $\left(10.5 \% \mathrm{O}_{2}, \mathrm{Hy}\right)$ conditions from gestational day 5 to 21 , their 7 -month-old adult male offspring were tested for blood pressure, vascular BK channel functions and expression using patch clamp and wire myograh technique, western blotting, and qRT-PCR. Results: Prenatal hypoxia increased pressor responses and vasoconstrictions to phenylephrine in the offspring. Wholecell currents density of BK channels and amplitude of spontaneous transient outward currents (STOCs), not the frequency, were significantly reduced in Hy vascular myocytes. The sensitivity of $\mathrm{BK}$ channels to voltage, $\mathrm{Ca}^{2+}$, and tamoxifen were reduced in Hy myocytes, whereas the number of channels per patch and the single-channel conductance were unchanged. Prenatal hypoxia impaired NS1102- and tamoxifen-mediated relaxation in mesenteric arteries precontracted with phenylephrine in the presence of $\mathrm{N}^{\omega}$-nitro-L-arginine methyl ester. The mRNA and protein expression of BK channel $\beta 1$, not the $\alpha$-subunit, was decreased in Hy mesenteric arteries. Conclusions: Impaired BK channel $\beta 1$-subunits in vascular smooth muscle cells contributed to vascular dysfunction in the offspring exposed to prenatal hypoxia.
\end{abstract}

(C) 2018 The Author(s)

Published by S. Karger AG, Basel

\section{Introduction}

Aseries of epidemiological and scientificevidence demonstrated thatadverseintrauterine conditions are associated with fetal programming increased risks of cardiovascular diseases B. Liu and Y. Liu contributed equally to this work,

Miao Sun

and Zhice $\mathrm{Xu}$ 
in later life [1-4], which is a result adaptive alterations in gene expression patterns and phenotype in response to the in utero insults at critical period of development, leading to permanent changes in tissue structures and functions predisposing the development of chronic conditions after birth [5]. Fetal hypoxia is a common complication in pregnancy, which can be caused from preeclampsia [6], placental insufficiency, compression of the umbilical cord [7], gestational diabetes [8], chorioamnionitis [9], and maternal obesity [1012]. Other adverse conditions that induce fetal hypoxia include pregnancy at high altitude [13-16], maternal smoking [17], maternal respiratory diseases and severe anaemia [18, 19]. Prenatal hypoxia has been shown in causing vascular dysfunction in the offspring, characterized by increased myogenic tone of mesenteric arteries (MAs), impaired NOdependent relaxation in resistance vessels, and increased microvascular stiffness [20-23]. However, the mechanisms underlying vascular dysfunction in the offspring by prenatal hypoxia was not fully understood, especially the knowledge of the ion channel functions in resistance arteries is limited.

The peripheral vascular tone in small arteries and arterioles is an important determinant of blood pressure (BP) and is primarily determined by contractile status of vascular smooth muscle cells (VSMCs) [24]. Mesenteric arteries are typical systemic arteries, abundance of VSMCs with small lumen diameter, playing a critical role in peripheral resistance [25]. Regulations of that vascular bed make significant contributions towards systemic BP. Membrane potential regulation by potassium currents in mesenteric artery smooth muscle cells (MASMCs) is important in arterial resistance [26-28]. In particular, the vascular large conductance $\mathrm{Ca}^{2+}$-activated $\mathrm{K}^{+}(\mathrm{BK})$ channels provide an endogenous compensatory mechanism to counter vasoconstriction, especially to intense myogenic constriction of resistance vessels exposed to high intraluminal pressures $[29,30]$. BK channels located on the plasma membrane are activated by intracellular local $\mathrm{Ca}^{2+}$ release [31]. Enhanced BK channel activities produce spontaneous transient outward currents (STOCs), leading membrane hyperpolarization and reduced $\mathrm{Ca}^{2+}$ influx by decreasing the activity of voltage dependent $\mathrm{Ca}^{2+}$ channels, and then causing vasodilatation [32].

Vascular BK channels are composed of at least two noncovalently associated subunits; the pore-forming $\alpha$-subunit (BK- $\alpha$ ) and an accessory $\beta 1$-subunit (BK- $\beta 1$ ) [33-35]. The $\alpha-$ subunit forms the $\mathrm{K}^{+}$selective pore, whereas the $\beta 1$-subunits, abundantly expressed in arterial smooth muscle cells, confers to increased intrinsic $\mathrm{Ca}^{2+}$ sensitivity of the BK channel $\alpha$-subunits [36, 37]. The important functional significance of $\beta 1$-subunits is underlined by the observation of reduced $\mathrm{Ca}^{2+}$ sensitivity of BK channels in $\beta 1$ null mice [38, 39]. Downregulation of BK channel $\beta 1$-subunits has been reported in cerebral VSMCs of hypertension rats [40], MASMCs of the patients with primary hypertension [41], and coronary VSMCs of Zucker diabetic fatty rats [42]. On the basis of these observations, this study determined the effects and mechanisms of chronic prenatal hypoxia on BK channel functions in MA myocytes from male adult offspring at 7 month old. The data achieved may help to further understand the mechanism of prenatal hypoxia-caused increase of risks in development hypertension in later life.

\section{Materials and Methods}

\section{Animals and Maternal Hypoxia}

All procedures performed were approved by the Institute Animal Welfare Committee, and in accordance with the Guide for the Care and Use of Laboratory Animals. Sprague-Dawley rats (Su Pusi Biotech., Suzhou, China) were acclimated for one week before mating. Rats were allowed free access to food and tap water and housed in a 12:12 light-dark cycle. Gestational day (GD) 0 was determined by the presence of vaginal plug following mating with a male rat. On GD 5, pregnant rats were randomized to normoxia control (Con, $\mathrm{n}=10$ ) and hypoxia (Hy, $\mathrm{n}=10$ ) group. The hypoxia group was placed in chambers with $10.5 \%$ oxygen from GD 5 to GD 20 using nitrogen, and then moved out from chambers at GD 21 before delivery. The control rats were treated with the same conditions except chambers filled with room air. All pups were weighed after birth, 8 pups per dam were randomly selected and used for the experiments [21].

\section{KARGER}




\section{Cellular Physiology Cell Physiol Biochem 2018;45:1603-1616 \begin{tabular}{l|l|l} 
and Biochemistry 10.1159/000487727 & $\begin{array}{l}\text { C } 2018 \text { The Author(s). Published by S. Karger AG, Basel } \\
\text { www.karger.com/cpb }\end{array}$ \\
\hline
\end{tabular}}

Liu et al.: Prenatal Hypoxia \& Hypertension Risks

\section{Surgery and blood pressure measurement}

Male adult offspring rats ( $\mathrm{n}=7$ each group) were used for in vivo cardiovascular experiments as previously described [43]. Briefly, rats were anesthetized with sodium pentobarbitone (50 mg/kg IP). Polyethylene catheters were introduced into the femoral artery and vein and were tunneled subcutaneously, externalized at the nape of the neck. After two days of recovery from surgery, blood pressure (BP) were recorded continuously in conscious, unrestrained rats using the Power-Lab system and software (AD Instruments, Bella Vista, New South Wales, Australia). The baseline BP was monitored for 60 minutes, then phenylephrine (PE, $10 \mu \mathrm{g} / \mathrm{kg}$ ) in $0.2 \mathrm{ml}$ saline was injected intravenously via the catheter. The drug dose was based on previous reports [44].

\section{Measurement of vessel tone}

Third-order of mesenteric arteries of 7-month-old offspring were carefully isolated from connective tissue and precisely cut into rings of same length $(2 \mathrm{~mm})$. Rings were suspended in organ chambers filled with $5 \mathrm{ml}$ of modified Krebs-Ringer bicarbonate solution (in mmol/L): $118 \mathrm{NaCl}, 25 \mathrm{NaHCO}_{3}, 4.7 \mathrm{KCl}, 2.5$ $\mathrm{CaCl}_{2}, 1.2 \mathrm{KH}_{2} \mathrm{PO}_{4}, 1.2 \mathrm{MgSO}_{4}$ and 11 glucose) maintained at $37^{\circ} \mathrm{C}$ and gassed with $95 \% \mathrm{O}_{2}-5 \% \mathrm{CO}_{2}(\mathrm{pH} 7.4$ with $\mathrm{NaOH}$ ). Each ring was suspended by two $40-\mu \mathrm{m}$ tungsten wires passed through the lumen, and then mounted in a myograph system (610M, Danish Myotechniques, Aarhaus, Denmark) and then equilibrate for 30 minutes before normalization to an internal diameter of 0.9 of L13.3kPa by using a normalization software package (Myodata, Danish Myotechnologies). This corresponds to a transmural pressure of approximately $90 \mathrm{mmHg}$. Repeatedly exposed to $\mathrm{KCl}(80 \mathrm{mmol} / \mathrm{L})$ to confirm vessel viability following normalization. After equilibration, vessel rings were incubated with the non-selective NOS inhibitor $\mathrm{N}^{\omega}$-nitro-L-arginine methyl ester (L-NAME, $\left.10^{-4} \mathrm{~mol} / \mathrm{L}\right)$ for $30 \mathrm{~min}$. Vessels were then stimulated with phenylephrine (PE) $\left(10^{-5}\right.$ $\mathrm{mol} / \mathrm{L}$ ), and when increased vascular tension was stable, cumulative concentrations of NS11021 (specific BK channel opener, $10^{-9}$ to $10^{-5} \mathrm{~mol} / \mathrm{L}$ ) or tamoxifen (Tam) $\left(10^{-9}\right.$ to $\left.10^{-5} \mathrm{~mol} / \mathrm{L}\right)$ were added into chambers. Changes in tension by NS11021 or Tam were expressed as a percent of the initial contraction induced by phenylephrine, the cumulative addition of the drugs in approximate one-half log increments.

\section{Vessel dissection and cell isolation}

Smooth muscle cells from mesenteric arteries were enzymatically dissociated as previously reported [42]. Briefly, the third-order MA was cut into pieces and placed on ice-cold $\mathrm{Ca}^{2+}$-free physiological saline solution (PSS), containing (in mmol/L): $137 \mathrm{NaCl}, 5.6 \mathrm{KCl}, 1 \mathrm{MgCl}_{2}, 10 \mathrm{HEPES}, 0.44 \mathrm{NaH}_{2} \mathrm{PO}_{4}, 0.42 \mathrm{Na}_{2} \mathrm{HPO}_{4}$, $4.2 \mathrm{NaHCO}_{3}$ and 10 glucose ( $\mathrm{pH} 7.4$ with $\mathrm{NaOH}$ ), and incubated for $\sim 40$ min at $37^{\circ} \mathrm{C}$ with $4 \mathrm{mg} \mathrm{ml}^{-1}$ papain (Solarbio, China), $2 \mathrm{mg} \mathrm{ml}^{-1} \mathrm{ABV}$ (BioSHARP, China), and $1 \mathrm{mg} \mathrm{ml}^{-1}$ dithiothreitol (BioSHARP, China). Then tissue was washed 3 times with ice-cold $\mathrm{Ca}^{2+}$-free PSS and triturated gently using a fire-polished wide bore pipette to release single smooth muscle cells. Liberated MA myocytes were then stored in $\mathrm{Ca}^{2+}$-free PSS at $4^{\circ} \mathrm{C}$ for electrophysiological experiments within $6 \mathrm{~h}$.

\section{Electrophysiology}

Whole-cell $\mathrm{K}^{+}$currents were recorded using the conventional whole-cell patch clamp configuration. Outward $\mathrm{K}^{+}$currents were recorded at a voltage range from -60 to $+60 \mathrm{mV}$ in $10 \mathrm{mV}$ voltage steps (500 ms duration) increments from a holding potential of $-70 \mathrm{mV}$. Whole-cell BK channel currents were obtained as iberiotoxin (IbTx, $100 \mathrm{nmol} / \mathrm{L}$ )-sensitive components by digital subtraction of traces recorded after exposure to IbTx from control traces. The bath solution contained (in mmol/L): $134 \mathrm{NaCl}, 6 \mathrm{KCl}, 1.8 \mathrm{CaCl}_{2}$, $1 \mathrm{MgCl}_{2}, 10$ HEPES and 10 glucose, $\mathrm{pH} 7.4$ with $\mathrm{NaOH}$. Pipette resistance was 3-5 $\mathrm{M} \Omega$ when filled with the internal solution which contained (in mmol/L): 110 potassium aspartate, $30 \mathrm{KCl}, 1 \mathrm{EGTA}, 0.85 \mathrm{CaCl}_{2}$, $3 \mathrm{Na}_{2} \mathrm{ATP}, 10$ HEPES and 10 glucose; $\mathrm{pH} 7.2$ with $\mathrm{KOH}$. Only recordings with a series resistance $<15 \mathrm{M} \Omega$, leakage current $<50 \mathrm{pA}$, and seal resistances $>2 \mathrm{G} \Omega$, were used for analysis. A P/4 protocols were used to subtract leak and capacitive current transients.

Spontaneous transient outward currents (STOCs) were recorded using the perforated whole-cell patch clamp configurations. Borosilicate glass electrodes (3-5 M $\Omega$ ) were filled with pipette solution, containing (in mmol/L): 110 potassium aspartate, $30 \mathrm{KCl}, 10 \mathrm{NaCl}, 10 \mathrm{HEPES}, 1 \mathrm{MgCl}_{2}, 0.05$ EGTA, and 0.25 amphotericin $\mathrm{B}$ (pH 7.2 adjusted using $\mathrm{KOH}$ ), the bath solution was same as the conventional whole-cell recording bath solution. STOCs were recorded over a range of holding potentials from -40 to $0 \mathrm{mV}$. STOCs were analyzed by using the Mini Analysis 6.0 program (Synaptosoft, inc., Decatur, GA). The criterion for a STOC was defined as the peak current amplitude equal to or more than three times the single channel amplitude. 
Single BK channel currents were recorded from fresh isolated rat MA myocytes using the inside-out patch-clamp configurations. Pipette and bath solutions contained (in mmol/L): $145 \mathrm{KCl}, 1 \mathrm{EGTA}, 10$ Hepes and 5 glucose, $\mathrm{pH} 7.2$ with $\mathrm{KOH}$ in pipette solutions and pH 7.4 with $\mathrm{KOH}$ in bath solution. The amount of $\mathrm{CaCl}_{2}$ needed to give the desire free $\mathrm{Ca}^{2+}$ concentration in the bath solution determined by using MaxChelator software (Chris Patton, Stanford University, USA). We used the number of channels in the patch (N) and the channel open probability (Po) as an index of the channel steady-state activity. The BK channel activity (NPo) was calculated using the following equation: $\mathrm{NPo}=\Sigma\left(\mathrm{t}_{1}+\mathrm{t}_{2} \ldots \mathrm{t}_{\mathrm{i}}\right)$, where $\mathrm{t}_{\mathrm{i}}$ is the relative open time (time open/ total time) for each channel level. Single channel open probability (Po) was calculated by dividing NPo by the total number of channels per patch. The total number of BK channels per patch was determined while patches were held at $+80 \mathrm{mV}$ in the presence of $10 \mu \mathrm{mol} / \mathrm{L} \mathrm{Ca}^{2+}$ in the bath solution [45]. Only recordings with stable Po values for a minimum of 2 minutes under each condition were analyzed. Voltage-sensitivity data was fit with the Boltzmann function: $\mathrm{Po}=1 / 1+\exp \left[-\mathrm{ZF} / \mathrm{RT}\left(\mathrm{V}-\mathrm{V}_{1 / 2}\right)\right]$, where $\mathrm{V}_{1 / 2}$ is the membrane potential for the half-maximal channel activation. The $\mathrm{Ca}^{2+}$-sensitivity data was fitted with the Hill equation: $\mathrm{Po}=\left[\mathrm{Ca}^{2+}\right]_{\mathrm{i}}$ $\eta^{\mathrm{H}} / \mathrm{K}_{\mathrm{d}} \eta^{\mathrm{H}}+\left[\mathrm{Ca}^{2+}\right]_{\mathrm{i}} \eta^{\mathrm{H}}$, where $\eta^{\mathrm{H}}$ is the Hill coefficient and $\mathrm{K}_{\mathrm{d}}$ is the dissociation constant.

For all patch-clamp experiments, an multiclamp 700B amplifier (Axon Instruments, Foster City CA) and Clampex 10.1 software (Molecular Devices) were used. Membrane currents were digitized at $10 \mathrm{kHz}$ and filtered at $2 \mathrm{kHz}$ with a 8 pole Bessel filter, and stored in a personal computer for subsequent analysis. Clampfit 10.1 (Axon Instruments Inc., Foster City, CA, USA) was used to analyze whole cell and single channel membrane currents. Cell capacitance was measured using the cancellation circuitry of the voltageclamp amplifier. Borosilicate glass electrodes (Sutter Instrument Co, Novato, CA; i.d. $0.86 \mathrm{~mm}$ and o.d. 1.50 $\mathrm{mm}$ ) were pulled with a horizontal pipette puller (P-97, Sutter Instrument Co, Novato, CA). All patch-clamp experiments were performed at room temperature $\left(23^{\circ} \mathrm{C}\right)$.

\section{Western blotting}

Frozen mesenteric arteries were homogenized in a lysis buffer containing: $50 \mathrm{mmol} / \mathrm{L}$ TrisCl buffer, 0.1 $\mathrm{mmol} / \mathrm{L}$ EDTA, $0.1 \mathrm{mmol} / \mathrm{L}$ EGTA (pH 7.5), 1\% v/v NP-40 and 0.1\% v/v SDS, 1\% w/v Na deoxycholic acid, with cocktail of protease inhibitors (Roche). The lystates were centrifuged (12, $000 \mathrm{rpm}$ for $30 \mathrm{~min}, 4^{\circ} \mathrm{C}$ ) and supernatant was collected. Protein concentrations were determined using Bradford method. Supernatants $\left(40 \mu \mathrm{g}\right.$ ) denatured in $1 \times$ loading buffer at $95^{\circ} \mathrm{C}$ for $5 \mathrm{~min}$ before separated on $7 \%$ (for BK- $\alpha$ ) or $12 \%$ (for BK- $\beta 1$ ) SDS polyacrylamide gel by electrophoresis and transferred to PVDF membranes (Immobilon-P, Millipore). The membrane was washed in tris-buffered saline with $0.1 \%$ tween 20 (TBST) and blocked with $5 \%$ skim milk powder dissolved in TBST at room temperature for $1 \mathrm{~h}$. Membranes were then incubated with anti-BK $\alpha$-subunit polyclonal antibody (1:500, Santa Cruz, CA, USA), anti-BK $\beta 1$-subunit polyclonal antibody (1:500, Santa Cruz, CA, USA), or anti- $\beta$ actin monoclonal antibody $(1: 5,000$; Beyotime Biotech, China), overnight at $4{ }^{\circ} \mathrm{C}$. Each Membrane was washed three times in TBST for $10 \mathrm{~min}$ and then incubated $(1 \mathrm{~h}$, room temperature) with horseradish peroxidase-conjugated donkey anti-goat (1:5, 000; Beyotime Biotech, China) or goat anti-mouse (1:5, 000; Beyotime Biotech, China) in TBST on a shaker. The immunoreactive proteins were identified by enhanced chemiluminescence and signals were recorded with UVP imaging system (EC3-Imaging-System, Upland, USA). Densitometry for immunoreactive bands was analyzed using Quantity One software (Bio-Rad) and protein expression was expressed as relative abundance normalized to $\beta$-actin.

\section{Quantitative Real-Time PCR (qRT-PCR)}

Total RNA was isolated from rat MAs using RNeasy Plus Mini kit (Qiagen, Valencia, CA) and equal amounts of RNA samples were reverse transcribed into cDNA using the SuperScript III First-Strand Synthesis System kit (Takara, Japan). Quantitative real-time PCR was performed using the iCycler, MyiQ two color Real time PCR Detection system (Bio-Rad, USA). Each sample was performed in triplicates and averaged. The reaction mix contained $1 \mu \mathrm{l}$ of cDNA, $0.5 \mu \mathrm{mol} / \mathrm{L}$ of forward and reverse primer each, $10 \mu \mathrm{l}$ of $2 \times$ SYBR Green MAter mix (Takara), and $8 \mu \mathrm{l}$ of RNAse free water, making a total reaction of $20 \mu \mathrm{l}$. The reaction conditions underwent the following program: one cycle for $5 \mathrm{~min}$ at $95^{\circ} \mathrm{C}, 40$ cycles at $95^{\circ} \mathrm{C}$, and $60^{\circ} \mathrm{C}$ for 15 seconds each. The relative gene expression was expressed as $2^{-\Delta \Delta C t}$ (where $\Delta \mathrm{Ct}=\mathrm{Ct}$ of target gene-Ct of internal control gene of $\beta$-actin). Oligonucleotide primers were synthesized by ShengGong Biotcch (Shanghai, China). The forward and reverse primer sequences as previously described [46].

\section{KARGER}




\section{Statistical analysis}

Results are presented as mean \pm standard error of mean (SEM). Statistical significance was determined by unpaired Student's t-test or two-way ANOVA with Bonferroni post test when appropriate. Data were analyzed and curve fitting using GraphPad Prism 5.0 software. A value of $P$ (two tailed) $<0.05$ was considered significant.

\section{Results}

\section{Body weight}

The birth weight of Hy offspring was significantly reduced compared with Con offspring (Fig. 1A). No significant differences were observed in body weight of Con rats and Hy rats at 7 month old $(P>0.05$, Fig. 1B).

Phenylephrine-increased pressor responses and vessel contractions in adult offspring perinatally exposed to hypoxia

In vivo blood pressure measurement showed that there were no significant differences in mean arterial pressure (MAP) between the Con and Hy groups at baseline (Fig. 2A). However, increased PE-induced pressure reflex response was higher in the offspring exposed to prenatal hypoxia than that of the control (Fig. 2A). Ex vivo vessel rings contraction experiment showed that the maximal response and $\mathrm{pD}_{2}$ values of PE-induced vasoconstrictions were significantly higher in mesenteric arteries of the hypoxia offspring (Fig. 2B).

Reduction of whole-cell BK channel current density in Hy mesenteric artery myocytes

The effect of iberiotoxin, a specific BK channel inhibitor, on whole cell $\mathrm{K}^{+}$ current density in MASMCs was examined. Cell capacitance in myocytes from $\mathrm{Hy}$ group (19.43 $\pm 2.11 \mathrm{pF}, \mathrm{n}=$ 24 cells from 7 dams) was not significantly different from Con $(19.60 \pm 1.85 \mathrm{pF}$, $\mathrm{n}=22$ cells from 7 dams) group. Whole cell $\mathrm{K}^{+}$current density (at +30 to $+60 \mathrm{mV}$ ) was significantly greater in Con cells than that in Hy cells (Fig. 3A,D). IbTx (100 nmol/L) markedly inhibited $\mathrm{K}^{+}$currents in both Con and Hy cells (Fig. 3B). IbTxinsensitive current density

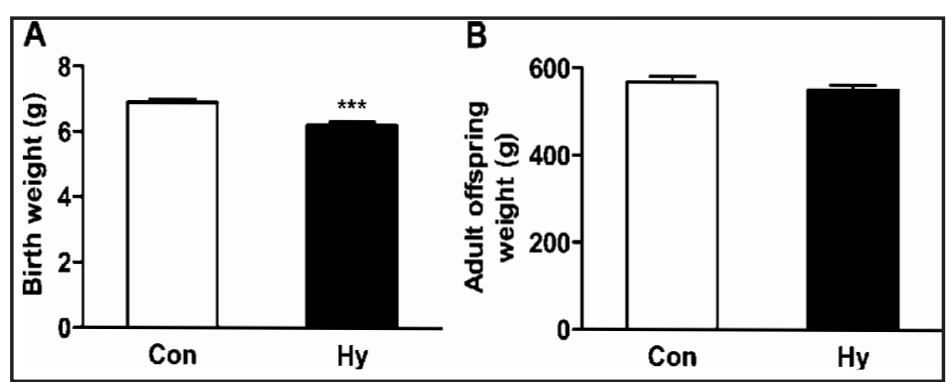

Fig. 1. Body weight. (A) Birth weight (Con=6.91 $\pm 0.1 \mathrm{~g}, \mathrm{n}=10$; $\mathrm{Hy}=6.22$ $\pm 0.11 \mathrm{~g}, \mathrm{n}=10$ ). (B) Body weight of male offspring rats at 7 month old (Con=568.10 $\pm 12.89 \mathrm{~g}, \mathrm{n}=15$ from 8 mothers; Hy=550.60 $\pm 11.49 \mathrm{~g}$, $\mathrm{n}=17$ from 9 mothers). ${ }^{* * *}, \mathrm{P}<0.001$ vs Con.

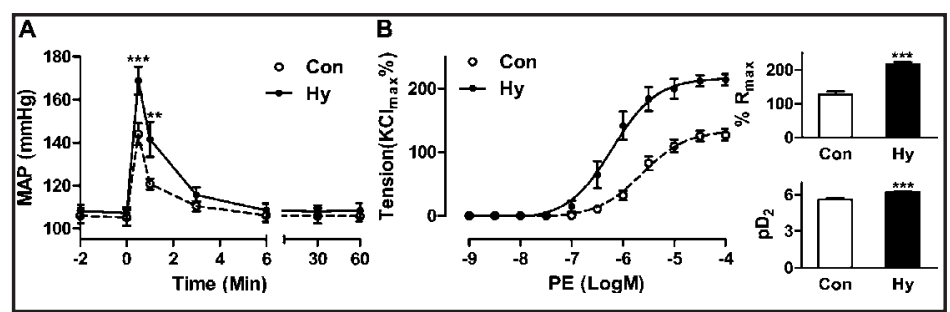

Fig. 2. The effect of prenatal hypoxia on phenylephrine (PE)-induced pressor responses and vasoconstriction in offspring mesenteric arteries (MA). (A) PE-increased mean arterial pressure (MAP) ( $n=6$ from 6 mothers each group). 0 min: time for intravenous injection of $\mathrm{PE}$ $(10 \mu \mathrm{g} / \mathrm{kg}$ ). (B) Cumulative dose-response contractions (maximal response, \%Rmax, and sensitivity, $\mathrm{pD}_{2}$ ) in the MA induced by PE (Con: $\% \mathrm{R}_{\max }=127.35 \pm 8.93, \mathrm{pD}_{2}=5.63 \pm 0.08 ; \mathrm{Hy}: \% \mathrm{R}_{\max }=214.00 \pm 8.75$, $\mathrm{pD}_{2}=6.21 \pm 0.09, \mathrm{n}=11$ vessel rings from 8 animals per group). The maximal contraction response $\left(\% \mathrm{R}_{\max }\right)$ was expressed as percentage of the maximal contraction induced by $80 \mathrm{mmol} / \mathrm{L} \mathrm{KCL}\left(\mathrm{K}_{\max }\right)$ and the vascular sensitivity was expressed as $\mathrm{pD}_{2}\left(-\operatorname{logEC} \mathrm{C}_{50}\right)$. **, $\mathrm{P}<0.01$, ***, $\mathrm{P}$ $<0.001$ vs Con. 


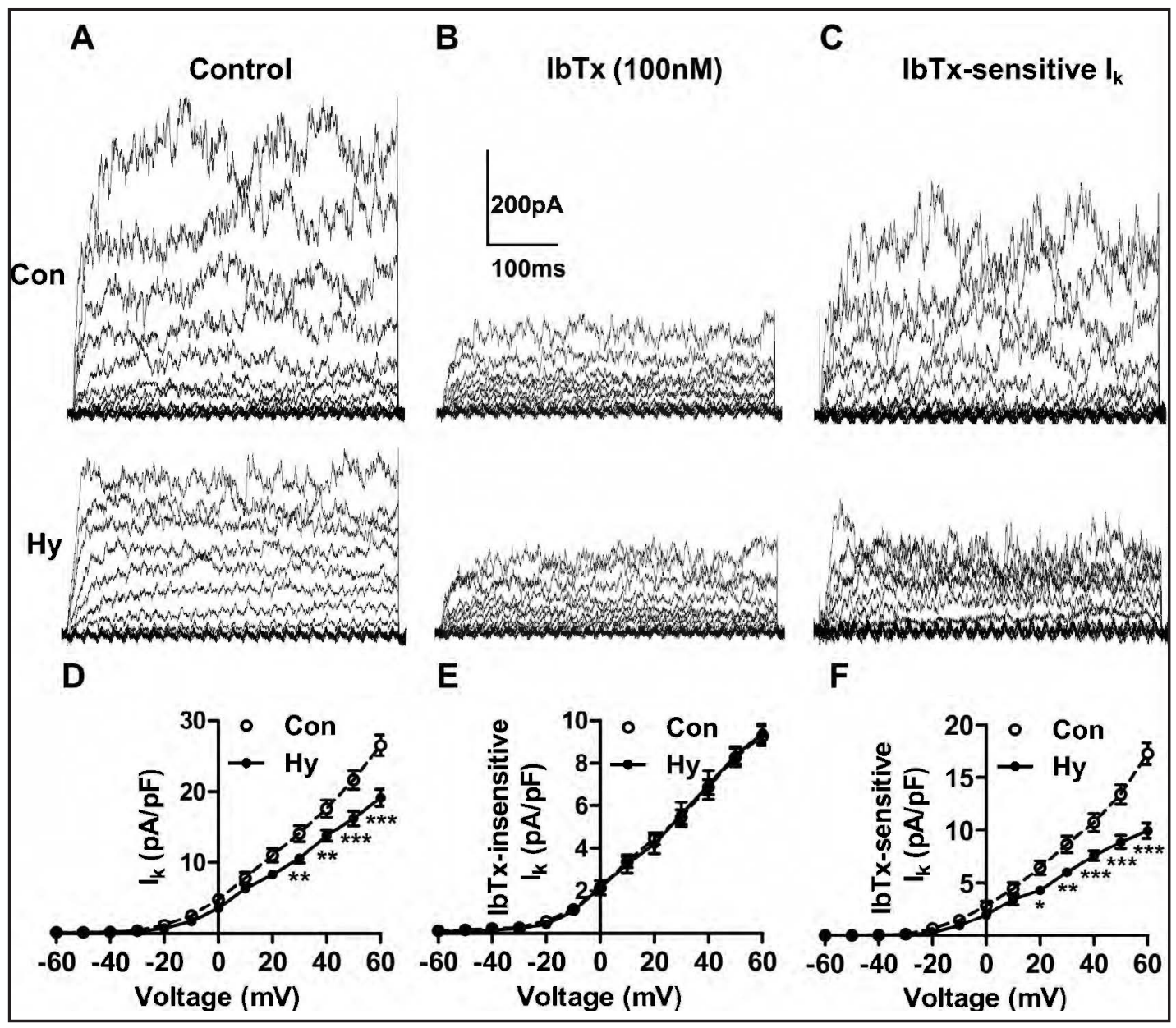

Fig. 3. Whole cell $\mathrm{K}^{+}$and $\mathrm{BK}$ channel current density is reduced in Hy cells. (A) Representative recordings of whole cell $\mathrm{K}^{+}$currents elicited by depolarizing voltage steps in a Con and Hy cell. (B) Inhibition of whole-cell $\mathrm{K}^{+}$currents by iberiotoxin (IbTx, $100 \mathrm{nmol} / \mathrm{L}$ ) in the same cells illustrated in A. (C) Iberiotoxin-sensitive $\mathrm{K}^{+}$ currents. (D) I-V relationships of mean whole cell $\mathrm{K}^{+}$current density $(\mathrm{pA} / \mathrm{pF})$ in Con and Hy cells $(\mathrm{n}=20$ cells per group). (E) I-V relationships of iberiotoxin-insensitive $\mathrm{K}^{+}$current density in Con and Hy cells ( $\mathrm{n}=20$ cells per group). (F) I-V relationships of iberiotoxin-sensitive $\mathrm{K}^{+}$current density in Con and Hy cells ( $\mathrm{n}=20$ cells per group). The whole-cell macroscopic current generated by $500-\mathrm{ms}$ voltage steps between -60 and +60 $\mathrm{mV}$ from a holding potential of $-70 \mathrm{mV}$. Cells from 7 dams per group; ${ }^{*}, \mathrm{P}<0.05$, **, $\mathrm{P}<0.01, * * *, \mathrm{P}<0.001$ vs Con.

was similar between the two groups. (Fig. 3B,E). IbTx-sensitive current density (at +20 to $+60 \mathrm{mV}$ ), which arises due to BK channel activation, was smaller in Hy cells than that in Con cells (Fig. 3C,F). These data suggest that prenatal hypoxia reduced the sarcolemmal current density of BK channels on MA myocytes from the offspring rats.

Amplitude of spontaneous transient outward currents decreased in mesenteric artery myocytes from Hy offspring

Spontaneous transient outward currents (STOCs) were recorded from mesenteric VSMCs at membrane potentials of $-40 \mathrm{mV}$ and $0 \mathrm{mV}$ using the perforated patch clamp configure (Fig. 4). At a physiological level of $-40 \mathrm{mV}$ and higher voltage of $0 \mathrm{mV}$, the mean amplitude of STOCs were significantly smaller in Hy than that in Con myocytes (Fig. 4A,B), whereas no differences were observed in frequency of STOCs between Con and Hy myocytes (Fig. 4A,C). These data suggested that mesenteric VSMCs from Hy presented less STOC activities than that from Con. 


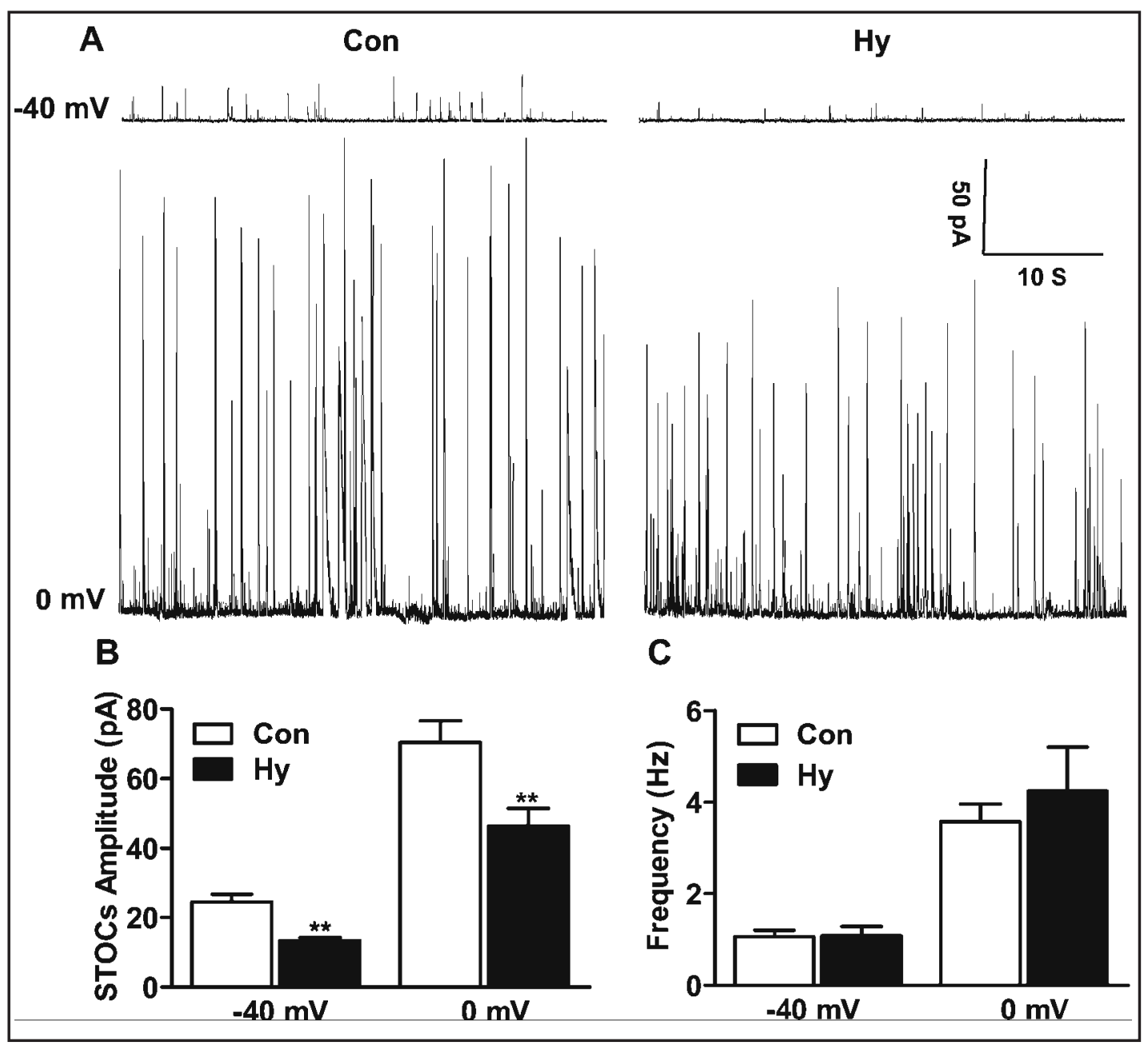

Fig. 4. Prenatal hypoxia inhibited spontaneous transient outward currents (STOCs) activity in offspring mesenteric arterial myocytes. (A) Representative recordings of STOCs recorded in Con and Hy MA myocytes at -40 and $0 \mathrm{mV}$. (B) Mean of STOCs amplitude at $-40 \mathrm{mV}$ (Con=24.42 $\pm 2.24 \mathrm{pA}, \mathrm{n}=13$ cells; Hy=13.36 \pm $0.88 \mathrm{pA}, \mathrm{n}=11$ cells) and $0 \mathrm{mV}$ (Con=70.22 $\pm 6.45 \mathrm{pA}, \mathrm{n}=11$ cells; $\mathrm{Hy}=46.37 \pm 5.08 \mathrm{pA}, \mathrm{n}=10$ cells). (C) Mean of STOCs frequency at $-40 \mathrm{mV}$ (Con=1.06 $\pm 0.14 \mathrm{~Hz}, \mathrm{n}=13$ cells; Hy=1.08 $\pm 0.20 \mathrm{~Hz}, \mathrm{n}=11 \mathrm{cells}$ ) and $0 \mathrm{mV}$ ( Con=3.58 $\pm 0.39 \mathrm{~Hz}, \mathrm{n}=11$ cells; $\mathrm{Hy}=4.24 \pm 0.95 \mathrm{~Hz}, \mathrm{n}=10$ cells). The cells from 7 animals per group, **, P $<0.01$ vs Con.

\section{$\mathrm{Ca}^{2+} /$ voltage-sensitivity of BK channels attenuated in MASMCs of Hy offspring}

$\mathrm{Ca}^{2+} /$ voltage-sensitivity of BK channels was tested using inside-out membrane patches from fresh dissociated small MASMCs (Fig. 5). The normalized NPo -voltage relations were determined at $1 \mu \mathrm{mol} / \mathrm{L} \mathrm{Ca}^{2+}$ concentration. (Fig. 5A,B ). There was a significantly right shift $(\sim 20 \mathrm{mV})$ for BK channels from Hy compared with Con. The half-maximal voltage of activation $\left(\mathrm{V}_{1 / 2}\right)$ for single BK channel was significantly increased in Hy myocytes compared to Con myocytes. The open probability (Po) at $+40 \mathrm{mV}$ was examined for a range of $\mathrm{Ca}^{2+}$ concentrations between 0.01-100 $\mu \mathrm{mol} / \mathrm{L}$ (Fig. 5C,D). The Po of BK channels from both Con and Hy myocytes was enhanced with increasing $\mathrm{Ca}^{2+}$ concentrations, the normalized NPo$\mathrm{Ca}^{2+}$ relationship curve of Hy was significantly right shifted compared with Con. The $\mathrm{K}_{d}$ value was significantly increased in Hy compared with Con, while no significant differences in the Hill coefficient (H) were observed between the two groups (Fig. 5D). These data indicated that the voltage and calcium sensitivity of single BK channel was attenuated in MA myocytes of Hy offspring.

\section{KARGER}




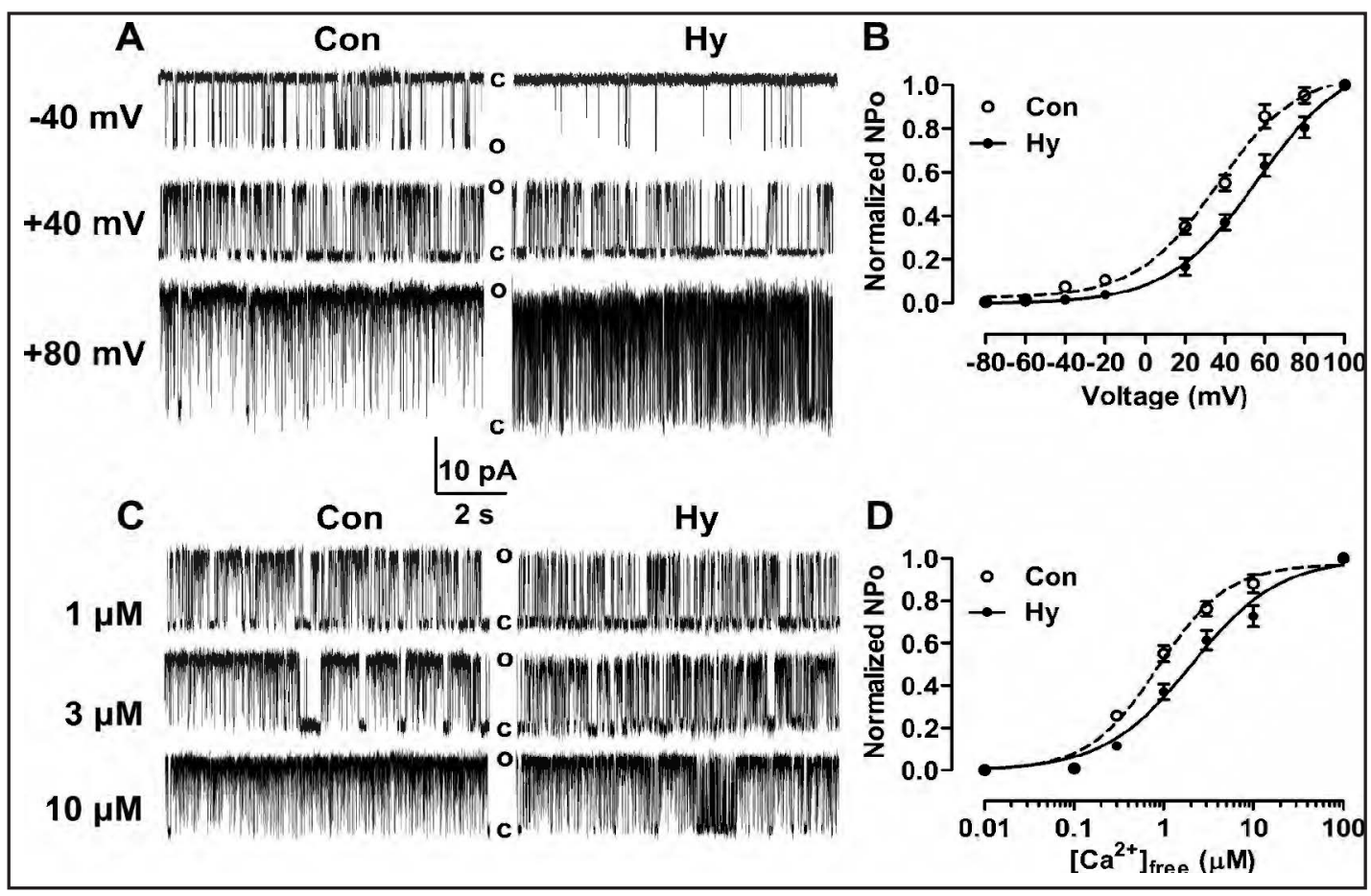

Fig. 5. Prenatal hypoxia reduced $\mathrm{BK}$ channel voltage sensitivity and $\mathrm{Ca}^{2+}$ sensitivity in offspring mesenteric arterial myocytes. (A) Exemplary single BK channel recordings from the same inside-out patches pulled from Con or Hy mesenteric arterial myocytes at $-40,+40$, or $+80 \mathrm{mV}$ in $\left[\mathrm{Ca}^{2+}\right]_{\mathrm{i}}$ at $10^{-6} \mathrm{~mol} / \mathrm{L}$. (B) Mean illustrating normalized BK channel open probability (Po) versus voltage ( $\mathrm{n}=20$ cells from 7 animals per group). Data are Boltzmann fits with the following parameters: Con $\left(\mathrm{V}_{1 / 2}=36.15 \pm 2.49 \mathrm{mV}\right)$, Hy $\left(\mathrm{V}_{1 / 2}=56.32 \pm 4.33 \mathrm{mV}\right)$, ***, $\mathrm{P}<0.001$. (C) Representative single BK channel recordings from inside-out patches pulled from Con or Hy mesenteric arterial myocytes with 1, 3, or $10 \mu \mathrm{mol} / \mathrm{L}$ free $\mathrm{Ca}^{2+}$ at $+40 \mathrm{mV}$. (D) Mean illustrating normalized BK channel open probability (Po) versus $\mathrm{Ca}^{2+}(\mathrm{n}=20$ cells from 7 animals per group). c, indicates closed channels; o, open channels. Data are fit with a Hill equation. Fit parameters are as follows: Con $\left(\mathrm{K}_{\mathrm{d}}=0.86 \pm\right.$ $0.09 \mu \mathrm{mol} / \mathrm{L}$, Hill slope=1.12 \pm 0.11$)$, Hy $\left(\mathrm{K}_{\mathrm{d}}=2.04 \pm 0.32 \mu \mathrm{mol} / \mathrm{L}\right.$, Hill slope=0.89 \pm 0.10$),{ }^{* *}, \mathrm{P}<0.01 .{ }^{* *}, \mathrm{P}$ $<0.01, * * *, \mathrm{P}<0.001$ vs Con.

\section{Gating and pharmacological properties of single BK channel}

As shown in Fig. 6A,B, single channel conductance of BK channels was similar for Con and Hy cells, and no differences in the number of BK channels per membrane patch in Con and Hy cells, indicating that the whole cell BK current density and STOCs amplitude were smaller in Con and Hy myocytes, as the result of lower BK channel sensitivity to $\mathrm{Ca}^{2+}$, and not because of a reduction in the number of BK channels or single-channel conductance.

As shown in Fig. 6C, the mean open dwell time of single BK channel $\left(1 \mu \mathrm{mol} / \mathrm{L}\left[\mathrm{Ca}^{2+}\right]_{\mathrm{i}^{\prime}}\right.$ $+40 \mathrm{mV}$ ) was significantly reduced in Hy myocytes compared with Con myocytes. Tamoxifen is known to activate BK channels only in the presence of regulatory $\beta 1$-subunits [45]. Under the condition at $+40 \mathrm{mV}$ with $100 \mathrm{nmol} / \mathrm{L}\left[\mathrm{Ca}^{2+}\right]_{i}$, BK channels from Hy myocytes were less sensitive to acute activation by $1 \mu \mathrm{mol} / \mathrm{L}$ tamoxifen than that in Con myocytes (Fig. 6D,E). These results indicated that down-regulation of $\mathrm{Ca}^{2+}$ - and voltage sensitivity of single BK channel in Hy myocytes may be result from a reduction of functional $\beta 1$-subunits.

\section{The effect of NS11021 and tamoxifen on vasoconstriction}

To exclude possibilities of endothelium derived nitric oxide on the activity of BK channel contribution to vascular tone, non-selective nitric oxide synthase inhibitor $\mathrm{N}^{\omega}$-nitro-larginine methyl ester (L-NAME, $100 \mu \mathrm{mol} / \mathrm{L}$ ) was added. To test the functional contribution of BK channels $\beta 1$ subunits to the regulation of vascular tone, selective channel opener (NS11021) and pharmacology probe (tamoxifen) of $\beta 1$-subunits were used. As shown in Fig. 


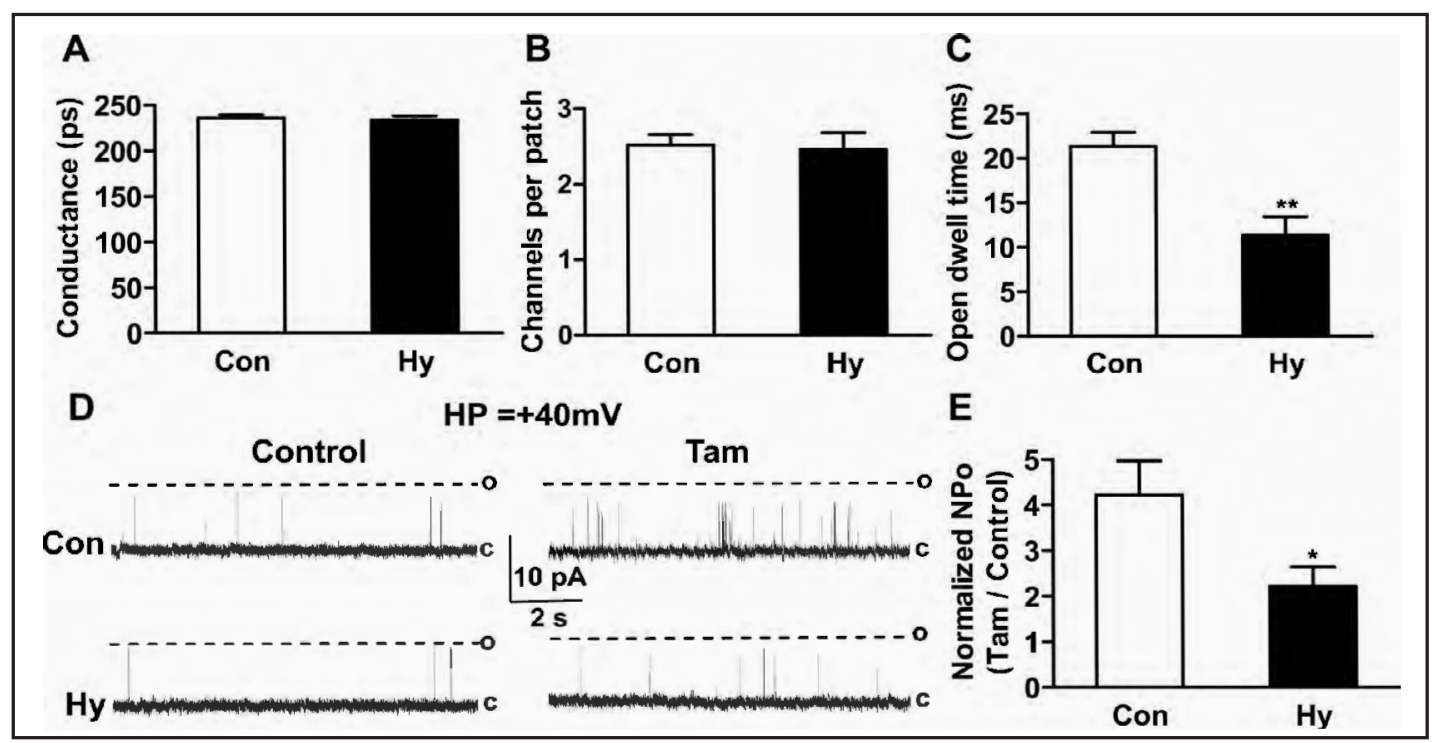

Fig. 6. The effect of prenatal hypoxia on gating and pharmacological properties of single BK channels in offspring mesenteric arterial myocytes. (A) Summary of the BK channel conductance in offspring mesenteric arterial myocytes (Con=236 $\pm 3.59 \mathrm{pS}, \mathrm{Hy}=234 \pm 4.54 \mathrm{pS}$; $\mathrm{n}=7$ cells from 7 dams/each group). (B) Estimated average number of channels per patch in Con $(2.52 \pm 0.14, n=30$ cells from 7 dams $)$ and Hy $(2.46 \pm 0.22$, $\mathrm{n}=30$ cells from 7 dams) myocytes. (C) Summary of mean dwell time of open state of BK channels at +40

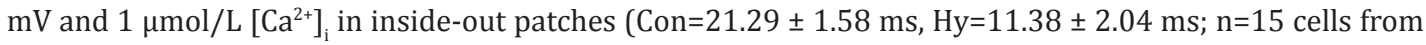

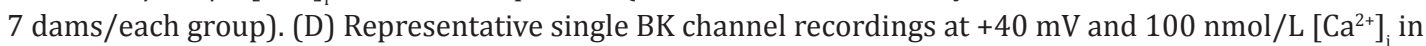
inside-out patches from Con and Hy myocytes before and after addition of $1 \mu \mathrm{mol} / \mathrm{L}$ tamoxifen (Tam). (E) Bar plot summarizes the fold change in the NPo of BK channels after the application of tamoxifen in Con ( $4.22 \pm 0.75$-fold, $n=7$ cells from 7 dams) and Hy (2.21 \pm 0.43 -fold, $n=8$ cells from 7 dams) myocytes. $c$, indicates closed channels and o, open channels. *, $\mathrm{P}<0.05$ vs Con.

7A, NS11021 $\left(10^{-9}\right.$ to $\left.10^{-5} \mathrm{~mol} / \mathrm{L}\right)$ was given in half-log increments. A parallel right shift of the concentration-relaxation curve was detected in Hy. The Value of $\% \mathrm{R}_{\max }$ and $\mathrm{pIC}_{50}$ of NS11021mediated relaxation on precontraction induced by PE were significantly decreased in Hy offspring, indicating that the contribution of BK channels to vascular tone was significantly decreased in Hy mesenteric arteries.

Fig. 7B showed the effect of tamoxifen $\left(10^{-9}-10^{-5} \mathrm{~mol} / \mathrm{L}\right)$ on mesenteric rings precontracted by $10^{-5} \mathrm{~mol} / \mathrm{L}$ PE. The maximal relaxation response $\left(\% \mathrm{R}_{\max }\right)$ and sensitivity of mesenteric artery $\left(\mathrm{pIC}_{50}\right.$ ) to tamoxifen were greater in Con than that in Hy, indicating that a reduction of $\mathrm{BK}$ channels in regulating MA tone may be due to dysfunction of $\beta 1$-subunits.

\section{mRNA and proteins expression of BK channel $\alpha$ - and $\beta 1$-subunits}

qRT-PCR showed that mRNA levels of BK- $\beta 1$, not BK- $\alpha$, in mesenteric arteries from Con were significantly higher than that from Hy (Fig. 8A,B). Western blots displayed that BK- $\beta 1$ protein expression was reduced in mesenteric arteries from Hy (Fig. 8D,F), whereas protein of BK- $\alpha$ was similar between the two proups (Fig. 8C,E). These dates indicated that the down-regulation of $\beta 1$ expression may be related to the reduced whole-cell currents, STOCs, and $\mathrm{Ca}^{2+}$ /voltage sensitivity of BK channels in MASMCs, as well as abnormal vascular tone in Hy offspring.

\section{Discussion}

The present study provides functional and molecular evidences for the first time that chronic prenatal hypoxia would decrease the effects of BK channels in regulating MA tone of 
Fig. 7. The effects of NS11021 on PE-induced MAs contraction from Mesenteric artery (MA) responses to NS11021 and tamoxifen. (A) Concentration-response curves for Con (pIC $_{50}=6.60 \pm 0.12$, $\% \mathrm{R}_{\max }=86.13 \pm 4.05 ; \quad \mathrm{n}=7 \quad$ animals) and Hy $\left(\mathrm{pIC}_{50}=5.88 \pm 0.11\right.$, $\% \mathrm{R}_{\max }=70.38 \quad \pm 5.10 ; \quad \mathrm{n}=7$ ). (B) Concentration-response curves for effects of tamoxifen on PE-induced contraction from Con $\left(\mathrm{pD}_{2}=6.69 \pm 0.11\right.$, $\% \mathrm{R}_{\max }=56.78 \pm 3.91, \quad \mathrm{n}=7$ ) and Hy $\quad\left(\mathrm{pIC}_{50}=6.21 \pm 0.17\right.$, $\% \mathrm{R}_{\max }=40.29 \pm 5.91 ; \mathrm{n}=7$ ). Curves are fit with a Hill equation. The maximal relaxant response $\left(\% \mathrm{R}_{\max }\right)$ was expressed as percentage of the precontraction induced by $\mathrm{PE}$ and the vascular sensitivity was expressed as $\mathrm{pIC}_{50}\left(-\log \mathrm{IC}_{50}\right)$. In each experiment, the arteries were preincubated with nonselective nitric oxide synthase inhibitor $\mathrm{N}^{\omega}$-nitro-l-arginine methyl ester (LNAME, $100 \mu \mathrm{mol} / \mathrm{L}$ ) for $30 \mathrm{~min}$. The responses to NS11021 and Tamoxifen are presented as the percentage of the precontraction to PE. *, $\mathrm{P}<0.05$, ***, $\mathrm{P}<0.001$ vs Con.

Fig. 8. mRNA and protein expression of BK channel $\alpha$ - and $\beta 1$ subunits in Con and Hy mesenteric arteries. Bar plots summarizing (A) BK- $\alpha$ and (B) BK- $\beta 1$ mRNA abundance in Con and Hy mesenteric arteries as determined by qRT-PCR ( $n=6$ animals per group). An example of Western blots of the (C) BK- $\alpha$ and (D) $\beta 1$ as well as $\beta$-actin expression in Con and Hy arteries were detected by Western blot. Qualitative analysis of the (E) BK- $\alpha$ and (F) $\beta 1$ protein expression levels in Con and Hy mesenteric arteries ( $\mathrm{n}=6$ per group). ${ }^{* *}, \mathrm{P}<0.01$ vs Con.

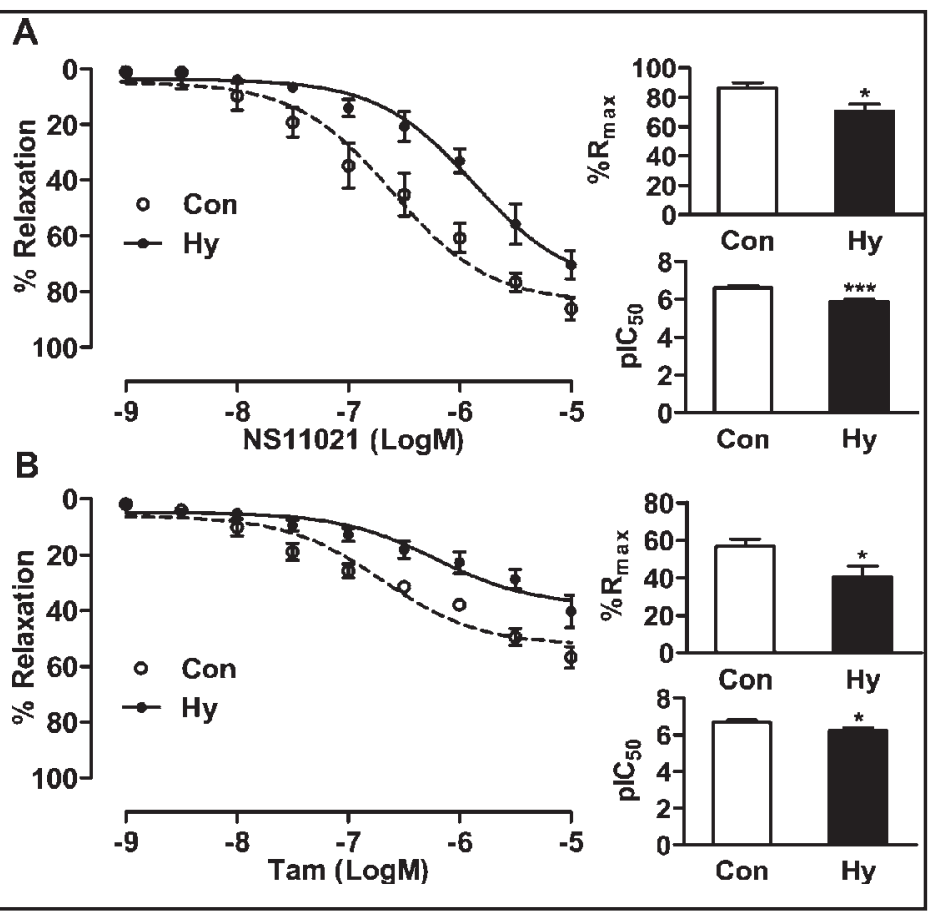

adult offspring by down-regulation of $\beta 1$-subunits in MA myocytes. The findings led to the hypothesis that attenuated $\beta 1$ expression may be an important event in the developmental changes in vascular functions by gestation hypoxia.

The present study first examined the effect of prenatal hypoxia on BP in conscious and free moving adult offspring rats. Previous reports demonstrated that the basal BP of offspring rats were not significantly changed by prenatal hypoxia with 10\% oxygen [48]. However, prenatal hypoxia significantly increased pressor responses to phenylephrine, consistent with the previous report [49]. These results indicated that prenatal hypoxia might contribute to an increased risk in fetal origin of hypertension in later life. 
Information is lacking regarding the effects of prenatal hypoxia on BK channel functions in the MA. In the present study, whole-cell recording demonstrated a significantly decrease in BK channel current density in MA myocytes from Hy offspring, similar to the previous report on the renal interlobar artery myocytes following prenatal hypoxia [49]. However, an early study demonstrated that prenatal hypoxia increased whole-cell BK channel current density and BK channel $\alpha$-subunit expression in pulmonary artery smooth muscle cells from male mice offspring [50]. The nature of those discrepancies may be caused by differences in animal strain, various organ used, and hypoxia conditions. In addition, perforated wholecell recording demonstrated that the amplitude of STOCs was significantly decreased in Hy cells. Prenatal exposure to caffeine decreased the amplitude of STOCs in MASMCs from adult male offspring [44]. Whole-cell BK channel currents and STOCs amplitudes should depend on number and activity (open times) of BK channels on membrane and singlechannel conductance. In the present study, it seems unlikely that the smaller whole-cell BK channel current density and STOCs amplitudes should be attributed to the conductance and functional number, because the conductance and functional number per patch were similar in the MASMCs from Con and Hy. Thus, the cause of the altered whole-cell BK channel current density and STOC amplitudes was most likely due to intrinsic decrease in BK channel activities. In supporting this hypothesis, our inside-out patch experiment revealed the characteristic features of the decreased BK channel activity, including a reduction of $\mathrm{Ca}^{2+}$ / voltage sensitivity and mean open dwell time.

Possible mechanism underlying the decreased $\mathrm{Ca}^{2+} /$ voltage sensitivity of BK channels and mean open dwell time in Hy cells was reduced $\beta 1$ subunit functions. $\beta 1$-subunits could increase $\mathrm{Ca}^{2+} /$ voltage sensitivity and open dwell time of BK channels $[36,51]$. Tamoxifen effect was shown only when it was associated with a $\beta 1$-subunits $[47,52]$. Thus, if $\beta 1$ subunit functions were attenuated in Hy myocytes, then tamoxifen increased the open probability (Po) of BK channels in Hy myocytes could be less than that in Con, as the present study found in Hy cells. Together, decreased $\mathrm{Ca}^{2+}$ sensitivity, shorter open time, and insensitivity to tamoxifen, strongly suggest that functions of BK $\beta 1$-subunits were damaged in the myocytes by prenatal hypoxia.

Isometric contraction experiments on third-order MA provided further evidence at micro-vessel level. Previous studies have demonstrated that the vascular endothelium generated NO could increase activities of BK channels in VSMCs [32]. Peroxynitrite (ONOO), formed in tissue by the nonenzymatic interaction between superoxide anion and nitric oxide (NO), could inhibit VSMCs BK channels [53]. In addition, hypoxia during late gestation reduced NO-mediated endothelial functions in rat offspring [21]. To clarify the effects of prenatal hypoxia on BK channel functions in MASMCs, vascular functions were tested in MAs with L-NAME (NO synthase inhibitor). In third-order MA pre-contracted by PE, the specific BK channel opener NS11021 [54] decreased vasodilatation in MAs from Hy offspring. In addition, the present study found tamoxifen-induced MA vasodilation was more effective in Con than Hy group. These data indicate that prenatal hypoxia-induced changes in BK channel-mediated vascular regulation by down-regulation of $\beta 1$-subunit functions were not subsequent to the decreased NO bio-availability or increased peroxynitrite production.

To explore the substantial molecular evidence, our biochemical study showed that the $\beta 1$-subunit functions were impaired in Hy MASMCs, as $\beta 1$-subunit protein expression was reduced in the MAs, whereas the $\alpha$-subunit expression was unchanged. These data were consistent with our observation of a similar number of BK channels in membrane patches between Hy and Con myocytes. Notably, similar phenomenon was also found in the MA of adult offspring exposed to prenatal caffeine [42]. Furthermore, qRT-PCR analysis demonstrated that mRNA expression of $\beta 1$-subunit, not $\alpha$-subunit, was reduced in Hy MAs. Hence, the molecular analysis supported our hypothesis that the down-regulation of $\beta 1$ subunits in the MA and cells of Hy offspring may be a critical target for prenatal hypoxia-caused vascular dysfunction in the MA. The outward $\mathrm{K}^{+}$current via BK channels is thought to serve as a negative feedback to hyperpolarize the membrane and buffer actions of vasoconstrictors in regulating arterial tone in resistance vessels [32]. It is rational to 
suggest that down-regulation of BK channel functions in VSMCs from Hy offspring may be led to enhance PE-mediated constriction in the present study, and as one of contributors to increased MA tone in Hy offspring. Limitations of the present study should be acknowledged, in spite of novel findings. First, it is worth to compare the results between male and female offspring following the prenatal insult. Second, if $\mathrm{Ca}^{2+}$ sparks in VSMCs of Hy offspring were also measured, additional information should be benefit in explanations of the underlying mechanisms.

\section{Conclusion}

To conclude, the data gained at molecular, cellular, and organ levels strongly support the hypothesis that chronic gestation hypoxia down-regulated the expression of BK channel $\beta 1$ subunits, leading to a decreased BK channel activity in VSMCs of adult male offspring. The findings bring new insight into the mechanism leading to vascular dysfunction by prenatal hypoxia and may help to identify new therapeutic targets in this setting.

\section{Acknowledgements}

Supported partly by National Nature \& Science Foundation of China (81320108006, 81570960, 81771592); Jiangsu Natural Science Foundation (BK20140292); and the Jiangsu Province's Key Discipline (Fetal Medicine).

\section{Disclosure Statement}

There are no conflicts of interest.

\section{References}

1 Barker DJ, Osmond C: Infant mortality, childhood nutrition, and ischaemic heart disease in England and Wales. Lancet 1986;1:1077-1081.

-2 Bateson P, Barker D, Clutton-Brock T, Deb D, D’Udine B, Foley RA, Gluckman P, Godfrey K, Kirkwood T, Lahr MM, McNamara J, Metcalfe NB, Monaghan P, Spencer HG, Sultan SE: Developmental plasticity and human health. Nature 2004;430:419-421.

-3 McMillen IC, Robinson JS: Developmental origins of the metabolic syndrome: prediction, plasticity, and programming. Physiol Rev 2005; 85:571-633.

4 Gluckman PD, Hanson MA, Cooper C, Thornburg KL: Effect of in utero and early-life conditions on adult health and disease. N Engl J Med 2008;359:61-73.

5 Louey S, Thornburg KL: The prenatal environment and later cardiovascular disease. Early Hum Dev 2005;81:745-751.

-6 Kingdom JC, Kaufmann P: Oxygen and placental villous development: origins of fetal hypoxia. Placenta 1997;18:613-621.

-7 Pardi G, Cetin I, Marconi AM, Lanfranchi A, Bozzetti P, Ferrazzi E, Buscaglia M, Battaglia FC: Diagnostic value of blood sampling in fetuses with growth retardation. N Engl J Med 1993;328:692-696.

-8 Escobar J, Teramo K, Stefanovic V, Andersson S, Asensi MA, Arduini A, Cubells E, Sastre J, Vento M: Amniotic fluid oxidative and nitrosative stress biomarkers correlate with fetal chronic hypoxia in diabetic pregnancies. Neonatology 2013;103:193-198.

-9 Maberry MC, Ramin SM, Gilstrap LC, Leveno KJ, Dax JS: Intrapartum asphypoxia in pregnancies complicated by intra-amniotic infection. Obstet Gynecol 1990;76:351-354. 


\section{Cellular Physiology Cell Physiol Biochem 2018;45:1603-1616 \begin{tabular}{l|l|l|l} 
DOI: 10.1159/000487727 & O 2018 The Author(s). Published by S. Karger AG, Basel \\
www.karger.com/cpb
\end{tabular}}

Liu et al.: Prenatal Hypoxia \& Hypertension Risks

10 Hayes EK, Lechowicz A, Petrik JJ, Storozhuk Y, Paez-Parent S, Dai Q, Samjoo IA, Mansell M, Gruslin A, Holloway AC, Raha S: Adverse fetal and neonatal outcomes associated with a life-long high fat diet: role of altered development of the placental vasculature. PLoS One 2012;7:e33370.

11 Kandadi MR, Hua Y, Zhu M, Turdi S, Nathanielsz PW, Ford SP, Nair S, Ren J: Influence of gestational overfeeding on myocardial proinflammatory mediators in fetal sheep heart. J Nutr Biochem 2013;24:19821990.

12 Dong M, Zheng Q Ford SP, Nathanielsz PW, Ren J. Maternal obesity, lipotoxicity and cardiovascular diseases in offspring. J Mol Cell Cardiol 2013;55:111-116.

-13 Makowski EL, Battaglia FC, Meschia G, Behrman RE, Schruefer J, Seeds AE, Bruns PD: Effect of maternal exposure to high altitude upon fetal oxygenation. Am J Obstet Gynecol 1968;100:852-856.

14 Giussani DA, Phillips PS, Anstee S, Barker DJ: Effects of altitude versus economic status on birth weight and body shape at birth. Pediatr Res 2001;49:490-494.

15 van Patot MC, Ebensperger G, Gassmann M, Llanos AJ: The hypoxic placenta. High Alt Med Biol 2012;13:176-184.

16 Soria R, Julian CG, Vargas E, Moore LG, Giussani DA: Graduated effects of high-altitude hypoxia and highland ancestry on birth size. Pediatr Res 2013;74:633-638.

17 Longo LD: Carbon monoxide: effects on oxygenation of the fetus in utero. Science 1976; 194:523-525.

18 Katz O, Sheiner E: Asthma and pregnancy: a review of two decades. Expert Rev Respir Med 2008;2:97-107.

19 Davis L, Thornburg KL, Giraud GD: The effects of anaemia as a programming agent in the fetal heart. J Physiol 2005;565:35-41.

20 Hemmings DG, Williams SJ, Davidge ST: Increased myogenic tone in 7-month-old adult male but not female offspring from rat dams exposed to hypoxia during pregnancy. Am J Physiol Heart Circ Physiol 2005;289:674-682.

-21 Williams SJ, Hemmings DG, Mitchell JM, McMillen IC, Davidge ST: Effects of maternal hypoxia or nutrient restriction during pregnancy on endothelial function in adult male rat offspring. J Physiol 2005b;565:125135.

-22 Giussani DA, Camm EJ, Niu Y, Richter HG, Blanco CE, Gottschalk R, Blake EZ, Horder KA, Thakor AS, Hansell JA, Kane AD, Wooding FB, Cross CM, Herrera EA: Developmental programming of cardiovascular dysfunction by prenatal hypoxia and oxidative stress. PloS One 2012;7:e31017.

23 Walton SL, Singh RR, Tan T, Paravicini TM, MoritzLate KM: Late gestational hypoxia and a postnatal high salt diet programs endothelial dysfunction and arterial stiffness in adult mouse offspring. J Physiol 2016;594:1451-1463.

-24 Hill MA, Yang Y, Ella SR, Davis MJ, Braun AP: Large conductance, $\mathrm{Ca}^{2+}$-activated $\mathrm{K}^{+}$channels $\left(\mathrm{BK}_{\mathrm{Ca}}\right.$ ) and arteriolar myogenic signaling. FEBS Lett 2010;584:2033-2042.

-25 Christensen KL and Mulvany MJ. Mesenteric arcade arteries contribute substantially to vascular resistance in conscious rats. J Vasc Res 1993;30:73-79.

-26 Nelson MT, Patlak JB, Worley JF, Standen NB: Calcium channels, potassium channels, and voltage dependence of arterial smooth muscle tone. Am J Physiol 1990;259:3-18.

-27 Cox RH, Folander K, Swanson R: Differential expression of voltage-gated $\mathrm{K}^{+}$channel genes in arteries from spontaneously hypertensive and Wistar-Kyoto rats. Hypertension 2001; 37:1315-1322.

-28 Ghisdal P, Morel N: Cellular target of voltage and calcium-dependent $\mathrm{K}^{+}$channel blockers involved in EDHFmediated responses in rat superior mesenteric artery. Br J Pharmacol 2001;134:1021-1028.

29 Berczi V, Stekiel WJ, Courtney SJ, Rusch NJ: Pressure-induced activation of membrane $\mathrm{K}^{+}$current in rat saphenous artery. Hypertension 1992;19:725-729.

-30 Brayden JE, Nelson MT: Regulation of arterial tone by activation of calcium-dependent potassium channels. Science 1992;256:532-535.

-31 Nelson MT, Cheng H, Rubart M, Santana LF, Bonev AD, Knot HJ, Lederer WJ: Relaxation of arterial smooth muscle by calcium sparks. Science 1995;270:633-637.

-32 Nelson MT, Quayle JM: Physiological roles and properties of potassium channels in arterial smooth muscle. Am J Physiol 1995;268:799-822.

33 Knaus HG, Garcia-Calvo M, Kaczorowski GJ, Garcia ML: Subunit composition of the high conductance calcium-activated potassium channel from smooth muscle, a representative of the mSlo and slowpoke family of potassium channels. J Biol Chem 1994;269:3921-3924. 


\section{Cellular Physiology Cell Physiol Biochem 2018;45:1603-1616 and Biochemistry DOI: 10.1159/000487727 2010 (0) 2018 The Author(s). Published by S. Karger AG, Basel

Liu et al.: Prenatal Hypoxia \& Hypertension Risks

-34 Tanaka Y, Meera P, Song M, Knaus HG, Toro L. Molecular constituents of maxi $\mathrm{K}_{\mathrm{Ca}}$ channels in human coronary smooth muscle: predominant $\alpha+\beta$ subunit complexes. J Physiol 1997;502:545-57

-35 Lu R, Alioua A, Kumar Y, Eghbali M, Stefani E, Toro L: MaxiK channel partners: physiological impact. J Physiol 2006;570:65-72.

-36 McManus OB, Helms LM, Pallanck L, Ganetzky B, Swanson R, Leonard RJ: Functional role of the beta subunit of high conductance calcium-activated potassium channels. Neuron 1995;14:645-650.

-37 Cox DH, Aldrich RW: Role of the $\beta 1$ subunit in large-conductance $\mathrm{Ca}^{2+}$-activated maxiK $\mathrm{K}^{+}$channel gating energetics: mechanisms of enhanced $\mathrm{Ca}^{2+}$ sensitivity. J Gen Physiol 2000;116:411-432.

-38 Brenner R, Perez GJ, Bonev AD, Eckman DM, Kosek JC, Wiler SW, Patterson AJ, Nelson MT, Aldrich RW: Vasoregulation by the $\beta 1$ subunit of the calcium activated potassium channel. Nature 2000;407:870-876.

-39 Pluger S, Faulhaber J, Furstenau M, Lohn M, Waldschutz R, Gollasch M, Haller H, Luft FC, Ehmke H, Pongs O: Mice with disrupted BK channel beta1 subunit gene feature abnormal $\mathrm{Ca}(2+)$ spark/STOC coupling and elevated blood pressure. Circ Res 2000; 87:53-60.

40 Amberg GC, Bonev AD, Rossow CF, Nelson MT, Santana LF: Modulation of the molecular composition of large conductance, $\mathrm{Ca}(2+)$ activated $\mathrm{K}(+)$ channels in vascular smooth muscle during hypertension. J Clin Invest 2003; 12:717-724.

41 Yang Y, Li P, Cheng J, Mao L, Wen J, Tan X, Liu Z, Liu Z, Zeng X: Function of $\mathrm{BK}_{\mathrm{Ca}}$ channels is reduced in human vascular smooth muscle cells from Han Chinese patients with hypertension. Hypertension 2013; 61:519525.

42 Lu T, Ye D, He T, Wang X, Wang H, Lee H: Impaired Ca ${ }^{2+}$-dependent activation of large-conductance $\mathrm{Ca}^{2+}$ activated $\mathrm{K}^{+}$channels in the coronary artery smooth muscle cells of Zucker diabetic fatty rats. Biophys J 2008; 95:5165-5177.

43 Shi L, Liu B, Li N, Xue Z, Liu X: Aerobic exercise increases $\mathrm{BK}_{\mathrm{Ca}}$ channel contribution to regulation of mesenteric arterial tone by up regulating $\beta 1$-Subunit. Exp Physiol 2013; 98:326-336.

44 Li N, Li Y, Gao Q, Li D, Tang J, Sun M, Zhang P, Liu B, Mao C, Xu Z: Chronic fetal exposure to caffeine altered resistance vessel functions via RyRs-BK ${ }_{\mathrm{Ca}}$ down-regulation in rat offspring. Sci Rep 2015;5:13225

45 Meera P, Wallner M, Jiang Z, Toro L: A calcium switch for the functional coupling between alpha (hslo) and beta subunits (kv, Ca $\beta$ ) of maxik channels. FEBS Lett 1996; 385:127-128.

-46 Yang Y, Murphy TV, Ella SR, Grayson TH, Haddock R, Hwang YT, Braun AP, Peichun G, Korthuis RJ, Davis MJ, Hill MA: Heterogeneity in function of small artery smooth muscle $\mathrm{BK}_{\mathrm{C}}$ : involvement of the $\beta 1$-subunit. J Physiol 2009; 12:3025-3044.

47 Dick GM, Rossow CF, Smirnov S, Horowitz B, Sanders KM: Tamoxifen activates smooth muscle BK channels through the regulatory $\beta 1$ subunit. J Biol Chem 2001; 276, 34594-34599.

-48 Peyronnet J, Dalmaz Y, Ehrst rom M, Mamet J, Roux JC, Pequignot JM, Thorén HP, Lagercrantz H: Longlasting adverse effects of prenatal hypoxia on developing autonomic nervous system and cardiovascular parameters in rats. Pflugers Arch 2002; 443:858-865.

49 Tang J, Zhu Z, Xia S, Li N, Chen N, Gao Q, Li L, Zhou X, Li D, Zhu X, Tu Q, Li W, Wu C, Li J, Zhong Y, Li X, Mao C, Xu Z: Chronic hypoxia in pregnancy affected vascular tone of renal interlobar arteries in the offspring. Sci Rep 2015; 5:9723.

50 Marino M, Beny JL, Peyter AC, Bychkov R, Diaceri G, Tolsa JF: Perinatal hypoxia triggers alterations in $\mathrm{K}^{+}$channels of adult pulmonary artery smooth muscle cells. Am J Physiol Lung Cell Mol Physiol 2007; 293:1171-1182.

51 Nimigean CM, Magleby KL: The $\beta$ subunit increases the $\mathrm{Ca}^{2+}$ sensitivity of large conductance $\mathrm{Ca}^{2+}$-activated potassium channels by retaining the gating in the bursting states. J Gen Physiol 1999; 113: 425-440.

52 Dick GM, Sanders KM: (Xeno)estrogen sensitivity of smooth muscle BK channels conferred by the regulatory $\beta 1$ subunit: a study of $\beta 1$ knockout mice. J Biol Chem 2001; 276:44835-44840.

53 Liu Y, Terata K, Chai Q, Li H, Kleinman LH, Gutterman DD: Peroxynitrite inhibits $\mathrm{Ca}^{2+}$-Activated $\mathrm{K}^{+}$Channel Activity in smooth muscle of human coronary arterioles. Circ Res 2002; 91:1070-1076.

54 Bentzen BH, Nardi A, Calloe K, Madsen LS, Olesen SP, Grunnet M: The small molecule NS11021 is a potent and specific activator of $\mathrm{Ca}^{2+}$-activated big-conductance $\mathrm{K}^{+}$channels. Mol Pharmacol 2007; 72:1033-1044. 